\title{
Association of IL-17A -197G/A (rs2275913) Single Nucleotide Polymorphism and Rheumatoid Arthritis in Sudanese Patients
}

Rgda Mohamed Osman

University of Medical Sciences and technology

Mounkaila Noma

University of Medical sciences and technology

Abdallah Elssir Ahmed

Alfarrabi College for Sciences and technology

Rihab Ali Omer

Universitat Leipzig

Musab M. Ali Albsheer

Sinnar University

Ayman Ali Mohammed Alameen

Al-Jouf University

Ali Mahmoud Mohammed Edris

University of Bisha

Mohamed S. Muneer

Mayo Clinic's Campus in Florida

Ayman Ahmed

University of Khartoum

Nouh Saad Mohamed

Alfarrabi College for sciences and technology

Emmanuel Siddig ( $\nabla$ emanwell-eds3@hotmail.com )

University of Khartoum https://orcid.org/0000-0001-6314-7374

\section{Research note}

Keywords: Interleukin17A, Rheumatoid arthritis, Sudanese population

Posted Date: July 16th, 2020

DOI: https://doi.org/10.21203/rs.3.rs-42648/v1 
License: (c) (i) This work is licensed under a Creative Commons Attribution 4.0 International License. Read Full License 


\section{Abstract}

Objectives: Rheumatoid arthritis (RA) is a chronic inflammatory autoimmune disease. The aim of this study is to determine the association of IL-17A -197G/A polymorphism with RA in Sudanese Patients. A descriptive cross-sectional study was conducted between March and December, 2018. Clinical and demographic data of the study participants were collected and analysed. All statistical tests were considered as statistically significant when $p<0.05$.

Results: The study population included 266 participants, 166 (63.1\%) were females [mean age $41.4 \pm 15.5$ years] and 97 (36.9\%) were males [mean age $36.2 \pm 16.0$ years]. Of the 266 participants, 31\% (85/266) were RA cases and $69 \%(181 / 266)$ were healthy controls. Prevalence of $I L-17 A$ genotypes among the study population was $52.6 \%$ (140/266) were AG heterozygote genotype, 38.4\% (102/266) were AA homozygote genotype, and 9.0\% (24/266) were GG homozygote genotype. Correlation of IL-17A genotypes was negatively statistically significant based on participants clinical status, and family history of RA, Pearson's correlation [ $r=-0.392, \mathrm{P}$ value 0.001$]$ and $[r=-0.226$, $\mathrm{P}$ value 0.001$]$, respectively, while positively statistically significant with gender, Pearson's correlation [ $r=0.140, P$ value 0.023$]$. Based on the duration of RA, no statistically significant correlation was observed, Pearson's correlation $[r=-0.138$, $P$ value 0.207].

\section{Introduction}

Rheumatoid arthritis (RA) is an autoimmune disease characterized by a chronic inflammatory response that affects various part of the human body. At late stages, RA leads to deformities of the joints and bones causing severe pain [1-5]. Certain factors were hypothesized to be involved in the induction and the development of RA; however, the most acceptable theory for the development of the disease is a multifactorial theory that involve the interaction of environmental and genetic background of patients and render them more susceptible to RA [6]. The disease severity is varied from one population to another; African populations, especially Sudanese had more severe form of the disease comparing to other countries [7].

The microenvironment is very critical for the disease progression and it usually impact treatment outcomes, in RA the affected site show an adherence of several types of inflammatory cells including polymorph nuclear cells and macrophages as well as T cells [8]. Growing body of evidence indicates the central role of $T$ cells in the pathophysiology of RA; as the patients carrying Human Leukocytes antigen (HLA) - DRB1 are more susceptible to disease development [9-12].

Recently, a newly discovered subset of T Helper cells which is known as TH 17 was reported to play a crucial role in host defense toward several infectious agents $[13,14]$. TH 17 cells form a family of cytokines which consist of IL-17A, IL-17B, IL-17C, IL-17D, IL-17E, and IL-17F[15, 16]. Recent study demonstrated the exact role of $I L-17$ in RA, the level of $I L-17$ expression, and the producing cells in the synovial fluid in RA patients showed increase in $I L-17$ level in the patients with RA [17]. Also, a correlation 
between $I L-17$ levels on serum and synovial fluid with various RA activity markers such as erythrocyte sedimentation rate (ESR), C-reactive protein (CRP), and rheumatoid factor (RF) [18]. Interestingly, in the IL$17 \mathrm{gene}$ there are several polymorphisms have been detected that may influence the expression of $/ L-17$ $[19,20]$. In this study we aimed to investigate the association between IL-17A -197G/A (rs2275913) polymorphism and RA among Sudanese patients.

\section{Materials And Methods}

\section{Study Design and Study Population:}

A descriptive cross-sectional hospital-based study was conducted at Zain medical center in Khartoum state, Sudan, from February 2017 to December 2018. Three $\mathrm{ml}$ of blood were collected into EDTA blood containers from each participant voluntary enrolled in our study after reading and signing the informedconsent, parents/guardians agreed and signed on the behalf of their children in case of an underage patient. Personal interviews with each participant/ his signatory guardian prior to the blood donation to obtain the demographics and clinical data of participants, including age, gender, locality, tribe, family history, and the duration of disease. All those who attended to the hospital for follow-up for RA were giving a similar chance to participate in the study. Also, apparently healthy co-patient individuals regardless of their age and gender were included as a control group. All participants diagnosed with autoimmune diseases other than RA were excluded from the study.

\section{DNA extraction and IL-17A Genotyping:}

The total genomic DNA was extracted from blood samples using QIAamp DNA Blood Mini Kit (Qiagen, Germany). Extracted DNA was checked for quality using nanophotometer (Implen, Germany) and stored at $-20{ }^{\circ} \mathrm{C}$ until $I L-17 A$ genotyping. $I L-17 A$ genotyping was done using polymerase chain reaction and restriction fragment length polymorphism techniques (PCR-RFLP). The primers used for amplifying the IL17A gene were adopted from Mohamed et al., [19]. PCR conditions were consisted of a pre-denaturation step of 4 minutes at $94^{\circ} \mathrm{C}$ and 40 cycles each of 30 seconds denaturation at $94{ }^{\circ} \mathrm{C}, 30$ seconds annealing at $55^{\circ} \mathrm{C}$ and 30 seconds elongation at $72{ }^{\circ} \mathrm{C}$. This was followed by a post-elongation step of 7 minutes at $72^{\circ} \mathrm{C}$. After obtaining PCR amplicons, fragmentation was done using Xag/ endonuclease according to manufacturer's instructions (Roche, Germany). Restriction fragments were loaded on $3 \%$ agarose gel and visualized using UV-transilluminator (Sigma Aldrich, Germany).

\section{Statistical analysis:}

Data were analyzed using the Statistical Package for the Social Sciences (SPSS v20). Fisher's exact test was used to test the differences in genotypes frequency. Pearson's $\chi 2$ test was used for the correlation of $I L-17 A$ genotypes with the study variables. A P value $<0.05$ was considered statistically significant.

\section{Results}




\section{Characteristics of the study population}

The study population included 266 participants, of them 166 (63.1\%) were females [mean age $41.4 \pm 15.5$ years] and $97(36.9 \%)$ were males [mean age $36.2 \pm 16.0$ years]. The study participants overall, aged between 1 and 85 years with average of 40 years. The participants were classified into $85(31.2 \%)$ cases and $181(68.8 \%)$ were controls. Based on age grouping, the age groups of 21-40 years followed by $41-$ 60 years were the most frequent age groups; with $106(39.8 \%)$ and 101 (38.0\%) participants, respectively. Whereas, the frequency of the remaining age groups was 35 (13.2\%) for 1-20 years, 23 (8.6\%) for $61-80$ years, and $1(0.4 \%)$ for the age group of more than 80 years.

Among the studied population, those were from Arab ethnicity were the most frequent; 109 (41.0\%). Also, those with a previous history of RA were $27(10.2 \%)$, whereas those with no family history constituted 239 (89.8\%). Based on duration of RA among the case group, the most frequent age group was 41-60 years; $53(62.3 \%)$. And the duration of RA among the case group included $42(49.4 \%)$ were having RA for less than 5 years, $29(34.1 \%)$ for $5-10$ years, and $7(8.2 \%)$ for each of $11-15$ years and $15-20$ years (Table 1). 
Table 1

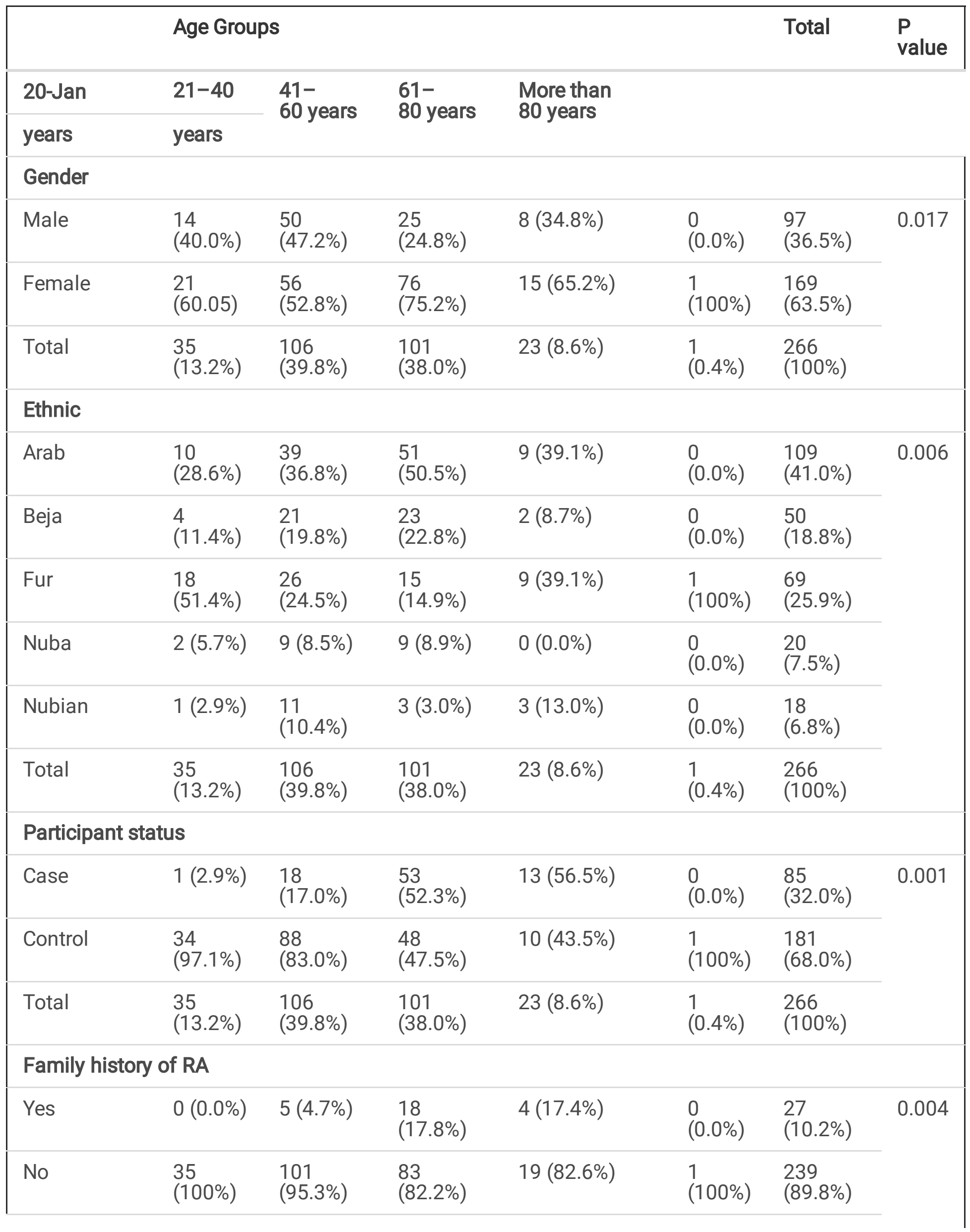




\begin{tabular}{|c|c|c|c|c|c|c|c|}
\hline & \multicolumn{5}{|c|}{ Age Groups } & \multirow{2}{*}{$\begin{array}{l}\text { Total } \\
266 \\
(100 \%)\end{array}$} & \multirow{2}{*}{$\begin{array}{l}P \\
\text { value }\end{array}$} \\
\hline Total & $\begin{array}{l}35 \\
(13.2 \%)\end{array}$ & $\begin{array}{l}106 \\
(39.8 \%)\end{array}$ & $\begin{array}{l}101 \\
(38.0 \%)\end{array}$ & $23(8.6 \%)$ & $\begin{array}{l}1 \\
(0.4 \%)\end{array}$ & & \\
\hline \multicolumn{8}{|c|}{ Duration of RA } \\
\hline $\begin{array}{l}\text { less than } \\
5 \text { years }\end{array}$ & $\begin{array}{l}1 \\
(100 \%)\end{array}$ & $\begin{array}{l}10 \\
(55.6 \%)\end{array}$ & $\begin{array}{l}27 \\
(50.9 \%)\end{array}$ & $4(30.8 \%)$ & $\begin{array}{l}0 \\
(0.0 \%)\end{array}$ & $\begin{array}{l}42 \\
(49.4 \%)\end{array}$ & \multirow[t]{5}{*}{0.672} \\
\hline $5-10$ years & $0(0.0 \%)$ & $6(33.3 \%)$ & $\begin{array}{l}16 \\
(30.2 \%)\end{array}$ & $7(53.8 \%)$ & $\begin{array}{l}0 \\
(0.0 \%)\end{array}$ & $\begin{array}{l}29 \\
(34.1 \%)\end{array}$ & \\
\hline $11-15$ years & $0(0.0 \%)$ & $1(5.6 \%)$ & $6(11.3 \%)$ & $0(0.0 \%)$ & $\begin{array}{l}0 \\
(0.0 \%)\end{array}$ & $7(8.2 \%)$ & \\
\hline $15-20$ years & $0(0.0 \%)$ & $1(5.6 \%)$ & $4(7.5 \%)$ & $2(15.4 \%)$ & $\begin{array}{l}0 \\
(0.0 \%)\end{array}$ & $7(8.2 \%)$ & \\
\hline Total & $1(1.2 \%)$ & $\begin{array}{l}18 \\
(21.2 \%)\end{array}$ & $\begin{array}{l}53 \\
(62.3 \%)\end{array}$ & $13(15.3 \%)$ & $\begin{array}{l}0 \\
(0.0 \%)\end{array}$ & $\begin{array}{l}85 \\
(100 \%)\end{array}$ & \\
\hline
\end{tabular}

\section{Prevalence of IL-17A genotypes in the study population}

The distribution of the different IL-17A genotypes among the study population was $52.6 \%(140 / 266)$ AG heterozygote genotype, 38.4\% (102/266) AA homozygote genotype, and 9.0\% (24/266) GG homozygote genotype. The heterozygote AG genotype was most frequent among those aged $41-60$ years; 63 (45.0\%), followed by 50 (35.7\%) among 21-40 years. While the homozygote AA genotype was most frequent among $21-40$ years followed by $41-60$ years; $46(45.1 \%)$ and 27 (26.5\%), respectively. Whereas, the homozygote GG genotype was frequent among 11 (45.8\%) of the age group 41-60 years followed by 10 (41.7\%) of the age group 21-40 years. A statistically significant difference was noted for the distribution of the different $I L-17 A$ genotypes among the different age groups, $P$ value 0.022 .

Based on the different ethnic groups of the study population, the homozygote AA genotype was more frequent among Fur; 31 (30.4\%), while the homozygote GG genotype was more frequent among Arab; 13 (54.2\%). Whereas, heterozygote AG genotype was among Arab ethnicity; 68 (48.6\%). The distribution of the different $I L-17 A$ genotypes among the different ethnic groups was statistically significant, $P$ value 0.034 .

Regarding the family history and duration of RA, the heterozygote AG genotype was found among 23 (16.4\%) of those with family history of RA, as well as those with duration of RA for less than 5 years; $36 / 85$ (55.4\%). However, a statistically significant difference was noted for the distribution of the different IL-17A genotypes according to family history, no statistically significant difference was seen fort the distribution of $I L-17 A$ genotypes according to duration of RA, $p$ values 0.001 and 0.321 , respectively (Table 2). 
Table 2

\begin{tabular}{|c|c|c|c|c|c|}
\hline & \multicolumn{3}{|c|}{ IL17Genotype } & \multirow[t]{2}{*}{ Total } & \multirow[t]{2}{*}{$P$ value } \\
\hline & $A A$ & GG & AG & & \\
\hline \multicolumn{6}{|l|}{ Age Group } \\
\hline $1-20$ years & $22(21.6 \%)$ & $1(4.2 \%)$ & $12(8.6 \%)$ & $35(13.2 \%)$ & \multirow[t]{6}{*}{0.022} \\
\hline $21-40$ years & $46(45.1 \%)$ & $10(41.7 \%)$ & $50(35.7 \%)$ & $106(39.8 \%)$ & \\
\hline $41-60$ years & 27 (26.5\%) & $11(45.8 \%)$ & $63(45.0 \%)$ & $101(38.0 \%)$ & \\
\hline $61-80$ years & $7(6.9 \%)$ & $2(8.3 \%)$ & $14(10.0 \%)$ & $23(8.6 \%)$ & \\
\hline More than 80 years & $0(0.0 \%)$ & $0(0.0 \%)$ & $1(0.7 \%)$ & $1(0.4 \%)$ & \\
\hline Total & $102(38.4 \%)$ & $24(9.0 \%)$ & $140(52.6 \%)$ & $266(100 \%)$ & \\
\hline \multicolumn{6}{|l|}{ Ethnic } \\
\hline Arab & $28(27.5 \%)$ & $13(54.2 \%)$ & $68(48.6 \%)$ & $109(41.0 \%)$ & \multirow[t]{6}{*}{0.034} \\
\hline Beja & 27 (26.5\%) & $2(8.3 \%)$ & $21(15.0 \%)$ & $50(18.8 \%)$ & \\
\hline Fur & $31(30.4 \%)$ & $4(16.7 \%)$ & $34(24.3 \%)$ & $69(25.9 \%)$ & \\
\hline Nuba & $9(8.8 \%)$ & $3(12.5 \%)$ & $8(5.7 \%)$ & $20(7.5 \%)$ & \\
\hline Nubian & $7(6.9 \%)$ & $2(8.3 \%)$ & $9(6.4 \%)$ & $18(6.8 \%)$ & \\
\hline Total & $102(38.4 \%)$ & $24(9.0 \%)$ & $140(52.6 \%)$ & $266(100 \%)$ & \\
\hline \multicolumn{6}{|l|}{ Family History of RA } \\
\hline Yes & $2(2.0 \%)$ & $2(8.3 \%)$ & $23(16.4 \%)$ & $27(10.2 \%)$ & \multirow[t]{3}{*}{0.001} \\
\hline No & $100(98.0 \%)$ & $22(91.7 \%)$ & $117(83.6 \%)$ & $239(89.8 \%)$ & \\
\hline Total & $102(38.4 \%)$ & $24(9.0 \%)$ & $140(52.6 \%)$ & $266(100 \%)$ & \\
\hline \multicolumn{6}{|l|}{ Duration of RA } \\
\hline less than 5 years & $2(28.6 \%)$ & $4(30.8 \%)$ & $36(55.4 \%)$ & $42(49.4 \%)$ & \multirow[t]{5}{*}{0.321} \\
\hline $5-10$ years & $3(42.9 \%)$ & $7(53.8 \%)$ & 19 (29.2\%) & $29(34.1 \%)$ & \\
\hline $11-15$ years & $1(14.3 \%)$ & $2(15.4 \%)$ & $4(6.2 \%)$ & 7 (8.2\%) & \\
\hline $15-20$ years & $1(14.3 \%)$ & $0(0.0 \%)$ & $6(9.2 \%)$ & 7 (8.2\%) & \\
\hline Total & $7(8.2 \%)$ & $13(15.3 \%)$ & 65 (76.5\%) & 85 (100\%) & \\
\hline
\end{tabular}




\section{Correlation of IL-17A genotypes with gender, family history of RA, and clinical status of the study participant}

The correlation of the different IL-17A genotypes was negatively statistically significant based on participants clinical status; case and control, and family history of RA, Pearson's correlation $[r=-0.392, p-$ value 0.001$]$ and $[r=-0.226, p$-value 0.001$]$, respectively. While correlation of $I L-17 A$ genotypes was positively statistically significant with participant gender, Pearson's correlation [ $r=0.140, p$-value 0.023 ]. Whereas based on the duration of RA, no statistically significant correlation was observed, Pearson's correlation [ $r=-0.138, p$-value 0.207$]$ (Table 3). 
Table 3

\begin{tabular}{|c|c|c|c|c|c|c|c|c|}
\hline & \multicolumn{3}{|c|}{ IL17 Genotypes } & \multirow[t]{2}{*}{$\begin{array}{l}M \pm \\
\text { STD }\end{array}$} & \multirow[t]{2}{*}{$\begin{array}{l}\text { Pearson's } \\
\text { r }\end{array}$} & \multirow[t]{2}{*}{$\begin{array}{l}P \\
\text { value }\end{array}$} & \multicolumn{2}{|c|}{$\begin{array}{l}95 \% \text { Confidence } \\
\text { Interval }\end{array}$} \\
\hline & AA & GG & AG & & & & $\begin{array}{l}\text { Lower } \\
\text { Bound }\end{array}$ & $\begin{array}{l}\text { Upper } \\
\text { Bound }\end{array}$ \\
\hline \multicolumn{9}{|c|}{ Participant status } \\
\hline Case & $7(6.9 \%)$ & $\begin{array}{l}13 \\
(54.2 \%)\end{array}$ & $\begin{array}{l}65 \\
(46.4 \%)\end{array}$ & \multirow[t]{2}{*}{$\begin{array}{l}1.68 \pm \\
0.467\end{array}$} & \multirow[t]{2}{*}{-0.392} & \multirow[t]{2}{*}{0.001} & \multirow[t]{2}{*}{1.62} & \multirow[t]{2}{*}{1.74} \\
\hline Control & $\begin{array}{l}95 \\
(93.1 \%)\end{array}$ & $\begin{array}{l}11 \\
(45.8 \%)\end{array}$ & $\begin{array}{l}75 \\
(53.6 \%)\end{array}$ & & & & & \\
\hline \multicolumn{9}{|l|}{ Gender } \\
\hline Male & $\begin{array}{l}47 \\
(46.1 \%)\end{array}$ & $\begin{array}{l}6 \\
(25.0 \%)\end{array}$ & $\begin{array}{l}44 \\
(31.4 \%)\end{array}$ & \multirow[t]{2}{*}{$\begin{array}{l}1.64 \pm \\
0.482\end{array}$} & \multirow[t]{2}{*}{0.14} & \multirow[t]{2}{*}{0.023} & \multirow[t]{2}{*}{1.58} & \multirow[t]{2}{*}{1.69} \\
\hline Female & $\begin{array}{l}55 \\
(53.9 \%)\end{array}$ & $\begin{array}{l}18 \\
(75.0 \%)\end{array}$ & $\begin{array}{l}96 \\
(68.6 \%)\end{array}$ & & & & & \\
\hline \multicolumn{9}{|c|}{ Family History } \\
\hline Yes & $2(2.0 \%)$ & $\begin{array}{l}2 \\
(8.3 \%)\end{array}$ & $\begin{array}{l}23 \\
(16.4 \%)\end{array}$ & \multirow[t]{2}{*}{$\begin{array}{l}1.9 \pm \\
0.303\end{array}$} & \multirow[t]{2}{*}{-0.226} & \multirow[t]{2}{*}{0.001} & \multirow[t]{2}{*}{1.86} & \multirow[t]{2}{*}{1.94} \\
\hline No & $\begin{array}{l}100 \\
(98.0 \%)\end{array}$ & $\begin{array}{l}22 \\
(91.7 \%)\end{array}$ & $\begin{array}{l}117 \\
(83.6 \%)\end{array}$ & & & & & \\
\hline \multicolumn{9}{|c|}{ Duration of RA } \\
\hline $\begin{array}{l}\text { less than } \\
5 \text { years }\end{array}$ & $\begin{array}{l}2 \\
(28.6 \%)\end{array}$ & $\begin{array}{l}4 \\
(30.8 \%)\end{array}$ & $\begin{array}{l}36 \\
(55.4 \%)\end{array}$ & \multirow[t]{4}{*}{$\begin{array}{l}2.75 \pm \\
0.925\end{array}$} & \multirow[t]{4}{*}{-0.138} & \multirow[t]{4}{*}{0.207} & \multirow[t]{4}{*}{2.55} & \multirow[t]{4}{*}{2.95} \\
\hline $5-10$ years & $\begin{array}{l}3 \\
(42.9 \%)\end{array}$ & $\begin{array}{l}7 \\
(53.8 \%)\end{array}$ & $\begin{array}{l}19 \\
(29.2 \%)\end{array}$ & & & & & \\
\hline $\begin{array}{l}11- \\
15 \text { years }\end{array}$ & $\begin{array}{l}1 \\
(14.3 \%)\end{array}$ & $\begin{array}{l}2 \\
(15.4 \%)\end{array}$ & $4(6.2 \%)$ & & & & & \\
\hline $\begin{array}{l}15- \\
20 \text { years }\end{array}$ & $\begin{array}{l}1 \\
(14.3 \%)\end{array}$ & $\begin{array}{l}0 \\
(0.0 \%)\end{array}$ & $6(9.2 \%)$ & & & & & \\
\hline
\end{tabular}

\section{Discussion}

Investigation of $I L-17 A$ polymorphisms among Sudanese population to determine the frequency distribution of the different $I L-17 A$ genotypes among healthy individuals [19]. in this study we investigated the frequency distribution of $I L-17 A$ genotypes among Sudanese patients diagnosed with RA and to determine the genetic susceptibility to RA in comparison to healthy individuals. The results of $I L$ $17 \mathrm{~A}$ genotypes distribution showed that the three genotypes were more prevalent in females compared to males, and among Sudanese Arab ethnic group. This result was similar to previous report, in which IL- 
17A polymorphism was significant among Sudanese Arab ethnic group [19]. As well as, the significant distribution of IL-17A genotypes among those with family history of RA, this could be attributed to the role of $I L-17 A$ SNPs inheritance to the descendants $[6,19]$. This was also supported by the negatively significant correlation of $I L-17 A$ with the family history of RA.

In this study, IL-17A genotypes showed a significant association to be linked with RA. This result is agreeing with a previously published systematic review including Fourteen studies and comprising more than three thousand patients with RA and more than two thousand healthy individuals to evaluate the relationship between serum level of IL-17 cytokine among RA patients and the possible SNPs that might be associated with the disease severity [21]. Their results showed a positive correlation between IL-17 level and RA compared to the control populations and they found some polymorphisms including $I L-17 A$ (rs2275913) was linked to increase the susceptibility toward developing the disease [21]. However, in a previous report investigated $I L-17 A$ (rs2275913) and the susceptibility to RA, the results showed that there were no statistically significant associations between $I L-17 A$ genotypes and the possibility of developing RA among Polish population [4]. And also, in a study conducted in a Tunisian population, IL-17A polymorphisms did not show any significant association with RA prevalence [22].

\section{Conclusion}

This study is the first study in Sudan established the association between IL-17A (rs2275913) polymorphisms and susceptibly to RA. These findings appeal for further research in various settings in Sudan to investigate the exact role of IL-17 in immunopathology and disease severity among Sudanese RA patients.

\section{Limitations}

- Analysis of further SNPs that found in the IL-17A gene could also be linked to RA.

- Functional analysis should be done to establish the effect of this SNP on the level of IL-17 and correlated the cytokine level with each genotyping and linked it to the outcome of the disease.

\section{Abbreviations}

DNA

Deoxyribonucleic acid; HLA:Human Leukocytes antigen; RA:Rheumatoid arthritis; IL 17A:Interleukin 17A

IFN-Y

Interferon gamma

IL-2

Interleukin 2

PCR

Polymerase chain reaction 
SNP

single nucleotide polymorphism

RF

rheumatoid factor

ESR

Erythrocyte sedimentation rate

CRP

$\mathrm{C}$ reactive protein

\section{Declarations}

\section{Ethics approval and consent to participate}

The study ethical approval was obtained from the Ministry of Health Ethical Committee on February 2018 (No. 1.2.2018). A written, informed consent was obtained from all the study participants.

\section{Consent to publish}

Not Applicable.

\section{Availability of Data and Materials}

The datasets used and/or analyzed during the current study are available from the corresponding author on reasonable request.

\section{Competing interests}

No competing interests to disclose.

\section{Funding}

Not Applicable.

\section{Authors' contributions}

RMO, AAM, AME, and EES designed and led the study. RMO, MN, AEA, RAO, NSM, MMA, AAM, AME and EES analyzed and interpreted the data. RMO, MN, AEA, RAO, NSM, MMA, AAM, AME and EES prepared the manuscript. All authors read and approved the final manuscript. 


\section{Acknowledgements}

The authors are grateful to the patients, controls and their families and the staff at the Zain Medical center, and Military hospital, Khartoum, Sudan, for their continued collaboration and generous hospitality during a decade of samples collection.

\section{References}

1. Dhaouadi T, Chahbi M, Haouami Y, Sfar I, Abdelmoula L, Ben Abdallah T, Gorgi Y. IL-17A, IL-17RC polymorphisms and IL17 plasma levels in Tunisian patients with rheumatoid arthritis. PLoS One. 2018;13(3):e0194883.

2. Pawlik A, Kotrych D, Malinowski D, Dziedziejko V, Czerewaty M, Safranow K. IL17A and IL17F gene polymorphisms in patients with rheumatoid arthritis. BMC Musculoskelet Disord. 2016;17(1):208.

3. Benedetti G, Miossec P. Interleukin 17 contributes to the chronicity of inflammatory diseases such as rheumatoid arthritis. Eur J Immunol. 2014;44(2):339-47.

4. Bogunia-Kubik K, Świerkot J, Malak A, Wysoczańska B, Nowak B, Białowąs K, Gębura K, Korman L, Wiland P. IL-17A, IL-17F and IL-23R gene polymorphisms in Polish patients with rheumatoid arthritis. Arch Immunol Ther Exp. 2015;63(3):215-21.

5. Hunt L, Emery P. Defining populations at risk of rheumatoid arthritis: the first steps to prevention. Nat Rev Rheumatol. 2014;10(9):521.

6. Nordang GB, Viken MK, Hollis-Moffatt JE, Merriman TR, Førre ØT, Helgetveit K, Kvien TK, Lie BA. Association analysis of the interleukin 17A gene in Caucasian rheumatoid arthritis patients from Norway and New Zealand. Rheumatology. 2009;48(4):367-70.

7. Elshafie Al, Elkhalifa AD, Elbagir S, Aledrissy MI, Elagib EM, Nur MA, Weitoft T, Rönnelid J. Active rheumatoid arthritis in Central Africa: a comparative study between Sudan and Sweden. J Rhuematol. 2016;43(10):1777-86.

8. Cope A, Schulze-Koops H, Aringer M. The central role of T cells in rheumatoid arthritis. Clinical experimental rheumatology. 2007;25(5):4.

9. Lee D, Weinblatt M. Rheumatoid arthritis. Lancet 2001:358.

10. Begovich AB, Carlton VE, Honigberg LA, Schrodi SJ, Chokkalingam AP, Alexander HC, Ardlie KG, Huang Q, Smith AM, Spoerke JM. A missense single-nucleotide polymorphism in a gene encoding a protein tyrosine phosphatase (PTPN22) is associated with rheumatoid arthritis. The American Journal of Human Genetics. 2004;75(2):330-7.

11. Simmonds $M$, Gough S. The HLA region and autoimmune disease: associations and mechanisms of action. Curr Genom. 2007;8(7):453-65.

12. Thorsby E, Lie BA. HLA associated genetic predisposition to autoimmune diseases: Genes involved and possible mechanisms. Transplant immunology. 2005;14(3-4):175-82. 
13. Gaffen SL. The role of interleukin-17 in the pathogenesis of rheumatoid arthritis. Curr Rheumatol Rep. 2009;11(5):365.

14. Ishigame H, Kakuta S, Nagai T, Kadoki M, Nambu A, Komiyama Y, Fujikado N, Tanahashi Y, Akitsu A, Kotaki $H$. Differential roles of interleukin-17A and-17F in host defense against mucoepithelial bacterial infection and allergic responses. Immunity. 2009;30(1):108-19.

15. Bettelli E, Korn T, Kuchroo VK. Th17: the third member of the effector T cell trilogy. Curr Opin Immunol. 2007;19(6):652-7.

16. Chabaud M, Durand JM, Buchs N, Fossiez F, Page G, Frappart L, Miossec P. Human interleukin-17: AT cell-derived proinflammatory cytokine produced by the rheumatoid synovium. Arthritis Rheumatism: Official Journal of the American College of Rheumatology. 1999;42(5):963-70.

17. Chabaud M, Durand JM, Buchs N, Fossiez F, Page G, Frappart L, Miossec PJA. Rheumatology ROJotACo: Human interleukin-17: AT cell-derived proinflammatory cytokine produced by the rheumatoid synovium. 1999, 42(5):963-970.

18. Rosu A, Margaritescu C, Stepan A, Musetescu A, Ene M. IL-17 patterns in synovium, serum and synovial fluid from treatment-naive, early rheumatoid arthritis patients. Rom J Morphol Embryol. 2012;53(1):73-80.

19. Mohamed NS, Siddig EE, Ahmed AE, Albsheer MMA, Abdelbagi H, Ali ET, Alsubki AA, Abdalaziz SA, Mustafa M, Muneer MS, et al. Frequency distribution of IL-17A G197A (rs2275913) and IL-17F A7488G (rs763780) polymorphisms among healthy Sudanese population. BMC Research Notes. 2020;13(1):317.

20. Ali ET, Masri MAM, Siddig EE, Ahmed A, Muneer MS, Mohamed NS, Edris AMM. Immunohistochemical expression of interleukin-17 and hormonal receptors in benign and malignant breast lesions. BMC Research Notes. 2020;13(1):300.

21. Marwa OS, Kalthoum T, Wajih K, Kamel H. Association of IL17A and IL17F genes with rheumatoid arthritis disease and the impact of genetic polymorphisms on response to treatment. Immunology letters. 2017;183:24-36.

22. Young BS. Genetics of rheumatoid arthritis contributes to biology and drug discovery. NATURE2014, 506(7488). 